\title{
ANONIMOWOŚĆ RODZICÓW GENETYCZNYCH A DOBROSTAN ZDROWOTNY DZIECKA. UWAGI NA TLE REKOMENDACJI 2156(2019) ZGROMADZENIA PARLAMENTARNEGO RADY EUROPY*
}

\section{UWAGI WSTĘPNE}

Stosowanie metod medycznie wspomaganej prokreacji jest faktem i życiową koniecznością w przypadku niemożności zajścia w ciążę i urodzenia dziecka w sytuacji wielu par pragnących potomstwa ${ }^{1}$. Wiedza medyczna pozwala na takie wykorzystanie technik leczenia niepłodności, że możliwe jest pominięcie jednego lub kilku etapów naturalnego zajścia w ciążę w obrębie dorosłej heteroseksualnej pary osób w wieku potencjalnie rozrodczym. Wykorzystanie, praktycznie nieograniczonej, technologii medycznej powinno jednak uwzględniać pewne ograniczenia stosowane w tym zakresie zgodnie z wolą poszczególnych ustawodawców ${ }^{2}$. Przy czym zwykle wola ta jest efektem pewnego kompromisu i musi uwzględniać różne wartości, które ustawodawca bierze pod uwagę, dopuszczając (lub zabraniając) powoływanie człowieka do życia poza organizmem jego matki bądź też z wykorzystaniem komórek niepochodzących od osób zainteresowanych projektem rodzicielskim ${ }^{3}$. Wielość możliwych konfiguracji i przypadków, które mogą zaistnieć z medycznego punktu widzenia, narzuca przyjęcie pewnych założeń wstępnych i przyjrzenie się jedynie kilku możliwym problemom badawczym. Zabieg taki jest usprawiedliwiony nie tylko chęcią udzielenia odpowiedzi na pewne szczegółowe pytania badawcze, lecz także kompleksowością wcześniej prowadzonych w literaturze analiz i uzyskanych wyników w tym zakresie ${ }^{4}$.

\footnotetext{
* Artykuł został przygotowany w ramach grantu Dziekana Wydziału Prawa i Administracji UAM, realizowanego na Università degli Studi Mediteranea Reggio Calabria (Włochy) 9.02.201921.02.2019 r.

${ }^{1}$ Baczyk-Rozwadowska (2018): 15.

${ }^{2}$ Zob. wykaz aktów prawnych prezentowany przez Bączyk-Rozwadowska (2018): 771-778.

${ }^{3}$ Może dojść do wykorzystania komórek osób zainteresowanych projektem rodzicielskim, ale z pominięciem ciąży kobiety, która będzie matką prawną. Oszkinis (2019): 112-225; Berti De Marinis (2014): 1715B.

${ }^{4}$ Haberko (2016): 1-468; (2012): 31-44; (2014b): 3-15; (2018a): 169-183; (2018b): 184-195; Haberko, Grabinski (2011): 33-61; Haberko, Sztandera (2017): 98-115; Łuczak-Wawrzyniak, Haberko (2015): 20-44.
} 
Przedmiotem artykułu jest jeden z problemów pojawiających się w związku z prawem do ustalenia własnego pochodzenia przez dziecko, które z niezależnych od siebie powodów, ale akceptowanych przez ustawodawcę, zostało pozbawione możliwości wychowania w rodzinie, w której rodzice prawni sa jednocześnie rodzicami genetycznymi. Jedynie na marginesie rozważań należy zauważyć, że problem dotyka wprawdzie wielu możliwych sytuacji faktycznych, ale z prawnego punktu widzenia będzie miał kluczowe znaczenie przy znanych prawu polskiemu anonimowej adopcji oraz zastosowaniu technik medycznie wspomaganej prokreacji z wykorzystaniem komórek rozrodczych od anonimowego dawcy, a także znanych innym systemom prawnym anonimowych porodach ${ }^{5}$. Oczywiście wskazanych przypadków nie można wprost zestawiać i traktować na równi, gdy chodzi o ochronę interesu dziecka, zarówno w zakresie realizacji jego dobra w ogólności, jak i w zakresie poznania swojej genetycznej tożsamości. We wszystkich wskazanych sytuacjach wyłącza się jednak w mniejszym bądź większym stopniu możliwość ustalenia pochodzenia człowieka zgodnie z prawda genetyczna ${ }^{6}$, w pewnym czasie lub w ogóle.

Analiza dotyczyć będzie postulowanych rozwiązań w zakresie stosowania instytucji anonimowości pochodzenia człowieka, poznania rodzica genetycznego oraz wpływu tej wiedzy na dobrostan zdrowotny człowieka ${ }^{7}$. Nie jest to problem nieznany prawu rodzinnemu, obecnie jednak nabiera zupełnie innego znaczenia niż jeszcze kilka czy kilkanaście lat temu ${ }^{8}$. O powadze i aktualności zagadnienia może świadczyć fakt wydania Rekomendacji 2156(2019) przez Zgromadzenie Parlamentarne Rady Europy w tym zakresie ${ }^{9}$. Zarówno w doktrynie, jak i na poziomie legislacyjnym podejmowane są coraz częściej inicjatywy zmierzajace do zmiany obecnego stanu rzeczy w kierunku zapewnienia możliwości ustalenia pochodzenia dziecka poczętego i urodzonego w wyniku zastosowania technik heterologicznych bądź dziecka, które nie poznało rodziców genetycznych z innych powodów (adopcja anonimowa, znalezienie w tzw. oknie życia, instytucja safe haven ${ }^{10}$ czy tzw. anonimowy poród) ${ }^{11}$. Jak się podkreśla, zgodnie z art. 8 Konwencji o ochronie praw człowieka i podstawowych wolności poznanie tożsamości rodziców, jest jednym z elementów prawa jednostki do poszanowania jej życia prywatnego i rodzinnego ${ }^{12}$, a obowiązek po-

${ }^{5}$ Por. Velletti (2017): 409-416; Vitale (2019); Santarsiere (2009): 1531; Grosso (2011): 208; Gigliotti (2017): 900; Lo Voi (2018): 1120; Cagnzzao (2017): 409-416; Vitale (2019); Klier et al. (2012): 428-434; Grylli et al. (2016): 291-297; Coutinho, Krell (2012).

${ }_{6}$ Tonolo (2014): 1123; Ballarani (2017): 965.

7 W literaturze pojawia się nawet termin: „oszołomienie genetyczne” na określenie sytuacji, w której człowiek nie posiada pełnej wiedzy o swoich genetycznych rodzicach. Oszkinis (2019) z powołaniem Sants (1964): 2; Szczucki (2010): 193-194, podaje przykład poważnej depresji powodowanej tym stanem.

${ }^{8}$ W ujęciu historycznym Bączyk-Rozwadowska (2018): 367-375.

${ }^{9}$ Anonymous donation of sperm and oocytes: balancing the rights of parents, donors and children, Recommendation 2156(2019), <assembly.coe.int> [dalej jako: Rekomendacja].

10 Kubicka-Kraszyńska (2017): 70 i literatura tam powołana.

11 Oszkinis (2019): 89 z powołaniem Laing (2006): 549; Grosso (2011): 208.

12 Oszkinis (2019): 314-325; Mostowik (2015): 311. 
szanowania prawa dziecka do poznania genetycznych rodziców jest wywodzony także z art. 8 Konwencji o prawach dziecka ${ }^{13}$.

Jak zauważono, wiedza o genetycznym pochodzeniu wpływa na zdrowotny dobrostan człowieka zarówno w aspekcie fizycznym, jak i psychicznym. Każdy człowiek ma bowiem genetyczną historię, którą odzwierciedlają najbliżsi krewni ${ }^{14}$. Wiedza o występujących w rodzinie chorobach genetycznych może w sposób zdecydowany wpłynaćc na zachowania człowieka w zakresie profilaktyki, diagnostyki i terapii. Można przyjąć, że wiedza ta zabezpiecza potencjalnie interesy człowieka w sferze medycznej ${ }^{15}$. Pomaga realizować uprawnienia w sytuacji pewnych zdarzeń zdrowotnych, w których konieczna jest np. transfuzja krwi czy przeszczep szpiku lub narządu od żywego dawcy ${ }^{16}$. Pozwala unikać zachowań potencjalnie skutkujących negatywnymi konsekwencjami w sferze zdrowia własnego lub innych osób. Wyłącza także niepewność co do potencjalności zachorowania na niektóre choroby ${ }^{17}$. Ma to znaczenie także w zakresie możliwości podejmowania szybko określonych działań dla ratowania życia i zdrowia ${ }^{18}$. Zachowania te zależą oczywiście od woli np. dawcy przeszczepu, niemniej jednak od razu znane sa osoby genetycznie spokrewnione z pacjentem, którego życie i zdrowie wymaga interwencji medycznej. System prawny wykształcił w tym zakresie pewne ułatwienia co do możliwości podejmowania decyzji i działania dla ratowania życia ${ }^{19}$. Brak zgodności genetycznej nie powoduje oczywiście niemożności osiagnięcia założonego stanu, niemniej jednak wymaga podjęcia pewnych dodatkowych działań w postaci zezwoleń odpowiednich organów ${ }^{20}$, wymaga też czasu dla ustalenia właściwej osoby, co niekiedy może być trudne, a w innych przypadkach może okazać się niemożliwe.

Aspekt psychiczny wskazanego wyżej dobrostanu zdrowotnego przejawia się w poczuciu własnego pochodzenia od osób, które człowiek uważa za genetycznie ze sobą spokrewnione. Chodzi w tym zakresie o brak konieczności zastanawiania się, czy rodzice, którzy wychowują człowieka i którzy sa nimi w świetle prawa, są nimi także genetycznie ${ }^{21}$. Oznacza to nie tylko realizację $\mathrm{w}$ sferze poznania swego pochodzenia, co oczywiście ma znaczenie dla zbudowania własnej genetycznej świadomości (lepszego zrozumienia siebie) ${ }^{22}$, lecz

13 Konwencja o ochronie praw człowieka i podstawowych wolności z 4 listopada 1950 r. (Dz. U. 1993, Nr 63, poz. 284 ze zm.; Konwencja o prawach dziecka z 20 listopada 1989 r. (Dz. U. 1991, Nr 120, poz. 1158).

14 Kapelańska-Pręgowska (2011); Skorek (2019).

15 Nesterowicz (2010): 116; (2005): 1205; Sośniak (1958): 116; Lewaszkiewicz-Petrykowska (1994): 47; Haberko (2014a): 45-64.

16 Haberko, Uhrynowska-Tyszkiewicz (2014): 117-140.

17 Jóźwiak (2000); Jolie (2013).

18 Dryla (2018): 91-105.

19 Zob. Haberko (2011): 44-54.

${ }^{20}$ Wytyczne Zespołu Prawnego Krajowej Rady Transplantacyjnej dla Komisji Etycznej w zakresie interpretacji klauzuli „szczególnych względów osobistych” przy pobraniu narządów od żywych dawców niespokrewnionych: <http://www.poltransplant.org.pl>.

21 Za zwrócenie uwagi na ten aspekt zagadnienia dziękuję Krzysztofowi Nizołkowi.

22 Zob. Krekora-Zając (2015): 131-132; sprawa Godelli v Italy, Application no. 33783/09 $<$ http://hudoc.echr.coe.int>. 
także pozbawia człowieka niepewności w zakresie nieświadomego wejścia $\mathrm{w}$ intymne relacje $\mathrm{z}$ krewnym genetycznym ze wszystkimi tego negatywnymi konsekwencjami ${ }^{23}$. Powyższe wyłącza również przypadki, w których człowiek dowiaduje się, gdy na przykład realizuje się dążenie do osiągnięcia dobrostanu w sensie fizycznym (należy przetoczyć krew lub dokonać przeszczepu), że osoby, które uważał za genetycznie ze sobą spokrewnione, nimi nie są. Nie można wówczas szybko podjacc kroków zmierzających do osiagnięcia poprawy zdrowia $\mathrm{w}$ sensie fizycznym, a dodatkowo traci się poczucie dobrostanu psychicznego.

\section{SYTUACJA DZIECKA ANONIMOWYCH GENETYCZNIE RODZICÓW}

Anonimowość genetycznego rodzica niezależnie od tego, czy jest efektem zastosowania technik polegajacych na wykorzystaniu komórek rozrodczych pochodzaccych od innych niż zainteresowani projektem rodzicielskim osób ${ }^{24}$, pozostawienia dziecka w tzw. oknie życia ${ }^{25}$ czy wiąże się z instytucją anonimowego porodu - może powodować wystapienie licznych zagrożeń medycznych, społecznych i prawnych zarówno dla urodzonego dziecka, jak i dla jego rodziców ${ }^{26}$. Zagrożeń tych poszczególni ustawodawcy nie mogą ignorować, przeciwnie: przy tworzeniu prawa powinni wziać je pod uwagę ${ }^{27}$. W pierwszej kolejności chodzi oczywiście o określenie przesłanek podmiotowych i przedmiotowych dopuszczalności stosowania technik medycznie wspomaganej prokreacji ${ }^{28}$, podobnie jak zasad ustalania pochodzenia dziecka znalezionego w tzw. oknie życia, pozostawionego w szpitalu, czy to w ramach tzw. anonimowego porodu, czy oddanego w ramach instytucji safe haven ${ }^{29}$. Każda ze wskazanych wyżej sytuacji jest oczywiście inna i wymaga szczegółowego podejścia ustawodawcy, który kierując się wyznawaną przez siebie aksjologia i zgodnie z reprezentowanym systemem wartości, będzie dążył do pogodzenia niekiedy sprzecznych interesów wielu podmiotów. Mając to na uwadze, musi on, uwzględniając podstawowe założenia systemu, kierować się nade wszystko zasadą dobra dziecka.

Nie wydaje się celowe poddanie analizie każdej z prezentowanych wyżej sytuacji, w której może nastapić założona przez ustawodawcę rozbieżność pochodzenia genetycznego i prawnego ${ }^{30}$, dlatego w poniższym wywodzie, ze

${ }^{23}$ Oszkinis (2019): 511; Haberko, Sztandera (2017): 98-115.

${ }^{24}$ Zob. Soniewicka (2018): 54-65.

25 Kadłubowska (2018): 1-74; Czapliński, Kroczek-Sawicka (2017): 42.

26 We Francji działa Narodowa Rada do spraw dostępu do informacji o swoim pochodzeniu (Conseil National pour l'accès aux origines personnelles, CNAOP);

${ }^{27}$ Ruszkiewicz (2014): 54; Żok, Rzymska (2015): 20; Hans-Bielut, Kroczek (2016): 15; Jarecka (2019); Ruszkiewicz (2019).

${ }^{28}$ Haberko (2016) i literatura tam zamieszczona.

${ }^{29}$ Kubicka-Kraszńska (2017): 72-73, zestawia skutki zarówno w zakresie anonimowości rodzica, jak i możności poznania swojego genetycznego pochodzenia przez dziecko.

30 Trzeba mieć na uwadze i to, że rozbieżność ta może być także efektem pewnych zdarzeń faktycznych w życiu określonych podmiotów: np. obcowanie kobiety zamężnej z innym niż mąż 
względu na ważkie konsekwencje rozważania ograniczone zostaną do sytuacji dążenia do zapewnienia realizacji zdrowotnego dobra dziecka poczętego i urodzonego z wykorzystaniem anonimowych komórek rozrodczych. Sytuacja ta jest inna niż wskazane wyżej, dlatego że nie stanowi wyjątku, nie jest efektem nadzwyczajnych wydarzeń w życiu rodzica, ale jest efektem świadomie dopuszczonego przez ustawodawcę działania.

Oczywiście problem rozbieżności w zakresie genetycznego pochodzenia człowieka i odzwierciedlenia tego faktu w aktach stanu cywilnego nie jest nowy i zwykle ustawodawcy przyjmuja pewne założenia w postaci wspartych doświadczeniem życiowych domniemań, na podstawie których możliwe jest osiagnięcie dobra dziecka przez ustalenie jego pokrewieństwa z innymi osobami $^{31}$. Domniemania te stanowia podstawę do przyjęcia, że dziecko pochodzi od określonych osób, w szczególności od ojca (art. 62 czy art. 85 Kodeksu rodzinnego i opiekuńczego ${ }^{32}$ ). Na tej podstawie ustala się relację o charakterze prawnym niezależnie od tego, jaka jest obiektywna genetyczna rzeczywistość. Zmiany w raz ustalonym pochodzeniu dziecka nie są dowolne, zwykle nie zależą od woli stron, co więcej, często ustawodawcy (np. wyznaczając określone terminy) ograniczą możliwość dochodzenia prawdy genetycznej, kierując się innym niż genetyczna zgodność z rodzicem interesem dziecka, w szczególności małoletniego ${ }^{33}$.

Jak wynika z powyższego, prawa do poznania tożsamości genetycznej nie należy utożsamiać i wiązać z uprawnieniem dziecka do zmiany ukształtowanego już stanu cywilnego. Przyjęcie odmiennej koncepcji mogłoby spotkać się z zarzutem niekonstytucyjności ${ }^{34}$. Nie można przyjąć bowiem zasady dowolnej zmiany raz ustalonego stanu cywilnego dziecka. Jeżeli przyjmuje się odstępstwo w tym zakresie, to jego źródłem jest m.in. ochrona dobra dziecka i jego praw. Jak zauważył Trybunał Konstytucyjny: „w polskim prawie rodzinnym nie respektuje się bezwzględnie prawa filiacji ojca biologicznego. [...] Elimino-

\footnotetext{
mężczyzną w wyniku czego dojdzie do urodzenia dziecka, które korzystać będzie z domniemania pochodzenia od męża matki, i ustalenie ojcostwa na podstawie oświadczenia przez kierownikiem USC w sytuacji braku biologicznych więzi między ojcem a dzieckiem. Przyjmując, że sytuacje te są raczej wyjątkowe i niepożądane oraz że system prawny pozwala, posługując się instytucjami zaprzeczenia ojcostwa oraz ustalenia bezskuteczności uznania, dojść do zgodności prawdy biologicznej z prawna, w poniższym wywodzie zostaną pominięte. Bogata literatura zebrana w: Pietrzykowski (2018): 562-568; Haberko, Sokołowski (2013): 519-521.

${ }^{31}$ Haberko (2018a):169-183.

${ }^{32}$ Ustawa 25 lutego 1964 r. - Kodeks rodzinny i opiekuńczy t.jedn.: Dz. U. 2019, poz. 2086 (dalej jako: k.r.o.).

${ }^{33}$ Wyrok z TK z 16 maja 2018 r., SK 18/17. Zgodnie z rządowym projektem ustawy o zmianie ustawy - Kodeks rodzinny i opiekuńczy (druk nr 3573) - art. 70 § 1 k.r.o. ma otrzymać następujące brzmienie: „dziecko po osiagnięciu pełnoletności może wytoczyć powództwo o zaprzeczenie ojcostwa w ciagu roku od dnia, w którym dowiedziało się, że nie pochodzi od męża swojej matki. Jeżeli dziecko dowiedziało się o okoliczności, o której mowa w zdaniu pierwszym, przed dniem osiagnięcia pełnoletności, termin do wytoczenia powództwa biegnie od dnia osiagnięcia pełnoletniości”. Zob. też sprawy Paulik v Stowacja, M. Mizzy v Malta, L. Shofman v Rosja, Y. Phinikaridou $v$ Cypr, Information Note on the Court's case-law, European Court for Human Rights, $<$ https://www.echr.coe.int>.

${ }^{34}$ Haberko, Sztandera (2017): 98-115.
} 
wanie z systemu prawnego możliwości ustalenia więzi rodzinnej zgodnie z rzeczywistością biologiczną musi jednak zawsze znajdować swoje uzasadnienie w innych wartościach konstytucyjnych" 35 .

Z tym poglądem można się oczywiście zgodzić, niemniej jednak należy mieć na uwadze dwoistość sytuacji, które moga tu wystapić. Po pierwsze, mogą się zdarzyć przypadki, w których - rzeczywiście - lepiej będzie nie dochodzić prawdy genetycznej w związku z ochroną innych wartości konstytucyjnych, w szczególności zaś dobra dziecka ${ }^{36}$. Jakkolwiek stanowisko to może być dyskusyjne w kontekście dążenia do zapewnienia człowiekowi zdrowotnego dobrostanu, niemniej jednak można przyjąć życzliwie, że stabilność ustalonych więzi rodzinnych, a zarazem brak pewności dojścia do nowych ustaleń, stoi w hierarchii wartości konstytucyjnych na równi ze zdrowiem człowieka lub nawet wyżej.

Po drugie jednak, mogą zaistnieć sytuacje, w których od początku zakłada się sprzeczność w analizowanym zakresie, i to dla realizacji interesu, który w hierarchii wartości konstytucyjnych plasuje się - obiektywnie - niżej, co więcej, nie obejmuje swym ochronnym zakresem dziecka. Drugi ze wskazanych przypadków zakłada od początku niemożność realizacji pewnych praw tylko dlatego, że chroni się interesy nie tyle dziecka, ile innych osób. Jak można sądzić, nie są to interesy zdrowotne ani związane ze stabilnością więzi rodzinnych.

Pierwsza i druga sytuacja różnią się zasadniczo. Otóż w pierwszym przypadku istnieje prawnie zagwarantowana możliwość dochodzenia ustalenia rzeczywistych relacji opartych na więzi krwi. Jest ona co najwyżej ograniczona do momentu uzyskania przez dziecko pełnoletności. Ograniczenie to jest jednak dyktowane - przez czas małoletności dziecka - innymi wartościami konstytucyjnymi. W drugim przypadku takiej możliwości nie ma.

Pokrewieństwo prawne w obliczu stosowania technik medycznie wspomaganej prokreacji zostało w przypadku wykorzystania komórek pochodzących od dawców anonimowych (a także zarodków pochodzących od anonimowych dawców) oddzielone od pokrewieństwa genetycznego, co więcej, system prawny nie dysponuje wspomnianymi wyżej instrumentami pozwalajacymi ustalić pochodzenie zgodnie $\mathrm{z}$ prawda genetyczna. Podobnie w pewnym sensie jest w przypadku adopcji anonimowej. Między dzieckiem a rodzicem adopcyjnym nie ma w ogóle więzi o charakterze genetycznym. Warto jednak pamiętać, że w przypadku adopcji anonimowej zasada, którą kieruje się sąd, jest zasada dobra dziecka, i to dla dziecka, które z jakichś powodów doświadczyło braku rodziców, dokonuje się wyboru rodziców ${ }^{37}$.

Mając powyższe na uwadze, ustawodawca w ustawie o leczeniu niepłodności wprowadza mechanizmy filiacyjne dostosowane do poszczególnych

35 Wyrok TK z 16 lipca 2007 r., SK 61/06, OTK ZU 2007, nr 7A, poz. 77.

${ }_{36}$ Mowa o ustalonej i stabilnej relacji osobistej dziecka i ojca, który nie kwestionuje realizacji obowiązków, zwłaszcza wówczas, gdy zaprzeczenie ojcostwa mogłoby skutkować szczególnymi trudnościami w ustaleniu pokrewieństwa z nowym ojcem (brak wiedzy o tej osobie fakt, że ojciec nie żyje itp.).

37 Łukasiewicz (2019): 105; Łączkowska (2008): 301-316. 
możliwych wariantów leczenia niepłodności, tj. art. 62 k.r.o, art. $75^{1}$ k.r.o., art. $81^{1}$ k.r.o., art. $85 \S 1$ k.r.o. ${ }^{38}$ Rozwiązania te - biorąc pod uwage wzmiankowaną wyżej wartość w postaci stabilności życia rodzinnego - zasługują na umiarkowanie pozytywną ocenę $e^{39}$. Ocena ta jest jednak inna, gdy mowa o zapewnieniu tożsamości genetycznej człowieka - realizacji dobrostanu zdrowotnego w aspekcie fizycznym i w aspekcie psychicznym. Intencją ustawodawcy pozostaje tu bowiem wyłącznie ochrona interesów dziecka w zakresie zabezpieczenia stabilności sytuacji rodzinnoprawnej ${ }^{40}$. Sa to wyłącznie rozwiązania o charakterze formalnoprawnym, zabezpieczające ustalenie pochodzenia z przyjętym założeniem rozbieżności pomiędzy rzeczywistością genetyczną a prawna ${ }^{41}$. Jak jednak słusznie zauważa się w literaturze, rozwiązania o charakterze formalnym dotyczace ojcostwa i macierzyństwa nie rozwiąuja wszystkich skutków pochodzenia człowieka ${ }^{42}$. Istnieją bowiem sytuacje uzasadniajace poznanie pochodzenia zgodnie z genetyczna prawda. Sytuacje te moga być rozwiązane przy wykorzystaniu konstrukcji prawa dziecka do znajomości swego pochodzenia genetycznego ${ }^{43}$, realizacja tego prawa pozostaje jednak de lege lata uzależniona od woli ustawodawcy ${ }^{44}$.

\section{SYTUACJA DZIECKA \\ POCZĘTEGO Z WYKORZYSTANIEM KOMÓREK ROZRODCZYCH POCHODZĄCYCH OD ANONIMOWEGO DAWCY}

W polskim systemie prawnym analizowaną kwestę reguluje art. 38 ust. 2 ustawy o leczeniu niepłodności ${ }^{45}$, który umożliwia osobie urodzonej wskutek zastosowania medycznie wspomaganej prokreacji w ramach anonimowego dawstwa oraz dawstwa zarodka, po osiagnięciu przez nią pełnoletności, dostęp do danych określonych w treści art. 37 ust. 2 pkt 2 i pkt 3 u.l.n. Dane te umieszczone są rejestrze, którego administratorem jest minister właściwy do spraw zdrowia. Chodzi tu o rok i miejsca urodzenia dawcy komórek rozrodczych lub dawców zarodka oraz informację na temat stanu zdrowia dawcy komórek rozrodczych lub dawców zarodka, tj. wyniki badań lekarskich i laboratoryjnych, którym poddany był kandydat na dawcę przed pobraniem komórek rozrodczych lub dawcy zarodka przed utworzeniem zarodka. Należy podkreślić, że osoba, która może uzyskać dostęp do informacji określonych w art. 37 ust. 2 pkt 3 u.l.n., jest także przedstawiciel ustawowy dziecka uro-

\footnotetext{
38 Haberko (2016): 406-418.

39 Haberko (2015): 175-194.

40 Safjan (1990): 55.

41 Cagnazzo (2017): 408.

42 Lipski (2015): 150.

43 Dyoniak (1996): 159.

44 Tendencje przedstawia Bączyk-Rozwadowska (2018): 375-393.

45 Ustawa z 25 czerwca 2015 r. o leczeniu niepłodności, t.jedn.: Dz. U. 2017, poz. 865 ze zm.
} (dalej jako: u.l.n.). 
dzonego w ten sposób. Uprawnienie, o którym mowa, przysługuje przedstawicielowi ustawowemu tylko wtedy, gdy informacje te moga przyczynić się do uchylenia bezpośredniego niebezpieczeństwa dla życia lub zdrowia tego dziecka.

Przyjęta konstrukcja nie jest godna akceptacji, i to z kilku powodów. Po pierwsze, należy zauważyć, że w katalogu informacji udostępnianych osobom upoważnionym brak danych umożliwiających pełną identyfikację dawców. To oznacza, że nie jest możliwe zrealizowanie dobrostanu zdrowotnego $\mathrm{w}$ aspekcie psychicznym. Z ogólnoludzkiego punktu widzenia rok i miejsce urodzenia człowieka niczemu nie służą. Osoba, która została poczęta i urodziła się z wykorzystaniem technik leczenia niepłodności, nie pozna imienia ani nazwiska swojego genetycznego ojca czy - w przypadku dawstwa zarodka - swoich genetycznych rodziców. Będzie jedynie wiedziała, że dawca urodził się w Krakowie czy w Poznaniu. Nie wpłynie to w żaden sposób na ustalenie jej genetycznej tożsamości, przypisania siebie do kręgu genetycznych krewnych, życia w poczuciu bycia krwia z krwi konkretnego rodzica czy rodziców. Wpływa natomiast na zdrowotny dobrostan w sensie psychicznym w tym zakresie, że wiąże się - a przynajmniej może - z niebezpieczeństwem negatywnych konsekwencji $\mathrm{w}$ zakresie potencjalnego pożycia cielesnego $\mathrm{z}$ bratem lub siostra ${ }^{46}$.

Po drugie, polski ustawodawca narusza zasadę poznania tożsamości genetycznej w ramach zapewnienia dobrostanu zdrowotnego w aspekcie fizycznym. Osoba, która została poczęta i urodzona z wykorzystaniem technik medycznie wspomaganej prokreacji w ramach dawstwa innego niż partnerskie ${ }^{47}$, została pozbawiona dostępu do innych informacji niezbędnych m.in. do prawidłowego postawienia diagnozy ewentualnych przyszłych chorób, np. danych dotyczących genotypu rodzica genetycznego, a także danych fenotypowych. Informacje, o których mowa w art. 37 ust. 2 pkt 3 u.l.n., nie sa bowiem dostatecznie sprecyzowane. Co więcej, możliwość przewidziana przez ustawodawcę można wykorzystać wyłącznie do sytuacji, które wystapiły po 1 listopada 2015 r. (tj. po wejściu w życie ustawy o leczeniu niepłodności), wyłącznie po osiagnięciu pełnoletności, a w przypadku przedstawiciela ustawowego - wyłącznie w sytuacji bezpośredniego niebezpieczeństwa, ale nie na wypadek przyszłych niebezpieczeństw.

Ustalony przez ustawodawcę zakres informacji udostępnianej osobie upoważnionej nakazuje przyjąć, że de lege lata nie zapewnia się realizacji prawa do poznania własnej tożsamości genetycznej jako prawa do informacji w zakresie genomu dawcy ani tym bardziej prawa do poznania tożsamości dawców komórek rozrodczych jako prawa do informacji w zakresie danych identyfikujących dawcę ${ }^{48}$. Określony tak zakres informacji nie realizuje więc ochrony prawa do zapewnienia zdrowotnego dobrostanu ani w aspekcie fizycznym, ani w aspekcie psychicznym. Trzeba mieć jednak świadomość, że zapewnienie

\footnotetext{
46 Haberko, Sztandera (2017): 98-115.

47 Haberko (2016): 38.

48 Lipski (2015): 150.
} 
tego stanu możliwe jest wyłącznie w sytuacji, w której nie będą realizowane ani zabezpieczone interesy teraz przez ustawodawcę respektowane. Mowa o prywatności życia rodzinnego i tajemnicy oraz anonimowości dawstwa komórek rozrodczych. Osiagnięcie tego stanu nie jest zadaniem niemożliwym, co nie oznacza, że jest zadaniem łatwym.

Ustawodawca musi bowiem uwzględniać następujące czynniki. Po pierwsze, należy wziąć pod uwagę fakt, że ustawa o leczeniu niepłodności obowiązuje od 2015 r., wcześniej techniki medycznie wspomaganej prokreacji były stosowane zgodnie z ogólnymi kryteriami wykonywania zawodu lekarza i zaleceniami towarzystw naukowych. Nie ulega watpliwości, że anonimowe komórki rozrodcze stosowano zarówno przed wejściem, jak i po wejściu w życie ustawy. Do tej pory zapewnia się dawcom gwarancję w postaci pełnej anonimowości dawstwa i wykorzystania komórek. Ewentualna zmiana legislacyjna w tym zakresie nie powinna - jak się wydaje - działać wstecz. Nie oznacza to jednak, że niemożliwe jest podjęcie próby rozstrzygnięcia dylematu zdrowotnego dobrostanu osób, które urodziły się w wyniku zastosowania technik z wykorzystaniem anonimowości dawców, zarówno przed wejściem w życie ustawy, jak i obecnie ${ }^{49}$.

Po drugie, o ile ustawodawca zdecydowałby się na ograniczenie zastosowania anonimowości dawstwa komórek rozrodczych, musiałoby się to wiązać z wprowadzeniem rozwiązań polegających bądź na zupełnym zakazie technik związanych z dawstwem innym niż partnerskie - co biorąc pod uwagę realia medyczne, nie wydaje się możliwe - bądź na wprowadzeniu zmian legislacyjnych w tym kierunku, że dziecko może poznać dane dawcy (dawców zarodka) nie tylko w ograniczonym - jak obecnie - zakresie, ale pełnym. Takie stanowisko ustawodawcy pozwoliłoby osiagnaćc dobrostan zdrowotny osób urodzonych z wykorzystaniem technik medycznie wspomaganej prokreacji. Możliwość poznania genetycznego rodzica wpłynęłaby na ustalenie własnej tożsamości człowieka, dałaby pewność genetycznego pochodzenia, zniwelowałaby niebezpieczeństwo kontaktów cielesnych z bratem lub siostra, a wreszcie pozwoliłaby poznać szczegółową genetyczną historię chorób.

Koncepcja ta ma oczywiście kilka słabych punktów, z którymi musiałby się zmierzyć ustawodawca. Po pierwsze, należałoby nałożyć na rodziców prawnych dziecka obowiązek poinformowania o fakcie poczęcia z wykorzystaniem komórek pochodzących od dawców. Taki obowiązek znany jest, w odniesieniu do przysposobienia, prawu włoskiemu ${ }^{50}$. Rzecz jasna ustawodawca nie określa, $\mathrm{w}$ jakim momencie powinno się to odbyćc ${ }^{51}$. Pokłada w tym zakresie zaufanie w rodzicach, którzy znając swoje dziecko, będą wiedzieli, kiedy jest najlepszy moment, by mu tę informację przekazać.

49 Propozycje w tym zakresie przedstawia: Bączyk-Rozwadowska (2018): 375-394.

${ }^{50}$ Legge 4 maggio 1983, n. 184; Cagnazzo (2017): 408; Abatantuono (2014/2015): 56.

51 Art. 28 comma 1: „Il minore adottato è informato di tale sua condizione e di genitori adottivi vi provvedono nei modi e termini che essi ritengono più opportuni"; Abatantuono (2014/2015): 56-58. 
Po drugie, dziecko, uzyskawszy wiedzę ${ }^{52}$ o fakcie poczęcia z wykorzystaniem anonimowych komórek rozrodczych, mogłoby podjać - zazwyczaj po osiagnięciu pełnoletności - decyzję w zakresie ustalenia swojego pochodzenia zgodnie z genetyczną rzeczywistością. Dałoby to możliwość realizacji uprawnień w zakresie osiagnięcia dobrostanu zdrowotnego. Trzeba by w tym zakresie przyjąć, że ochrona wartości, jaką jest życie prywatne i anonimowość dawcy komórek rozrodczych, musi ustapić realizacji interesu, którego człowiek został niezależnie od siebie pozbawiony w wyniku decyzji innych osób.

Anonimowość rodzica, jeżeli była przez ustawodawcę zagwarantowana w momencie, w którym doszło do poczęcia, a nawet do urodzenia czy sporządzenia aktu urodzenia, powinna być respektowana ${ }^{53}$. Nie wydaje się możliwe jej zniesienie z datą wsteczna. Może się jednak okazać, że już po czasie rodzic anonimowy kierowany różnymi motywami wyrazi zgodę na zniesienie anonimowości. Uwzględniając regulacje dotyczące zbliżonych przypadków (anonimowe porody), nie można wykluczyć zmiany decyzji rodzica w tym zakresie. Nie jest to oczywiście rozwiązanie optymalne, gdyż to do niego należeć będzie ostateczna decyzja co do ujawnienia tożsamości, niemniej jednak daje to szansę zmiany sytuacji, która bez decyzji anonimowego rodzica nigdy zmieniona by nie była ${ }^{54}$. Rozważyć można $\mathrm{w}$ tym zakresie konstrukcję wniosku kierowanego do odpowiedniego organu (są), by ten zwrócił się do anonimowego rodzica z zapytaniem o możliwość ujawnienia danych.

\section{POSTULATY DE LEGE FERENDA}

Podsumowując, problemy szczegółowe, które pojawiają się w związku z wykorzystaniem komórek pochodzących od dawcy anonimowego, można sprowadzić do konieczności uwzględnienia interesu dziecka przez: po pierwsze, zabezpieczenie prawnej relacji z przyszłymi rodzicami niezależnie od tego, czy relacja ta będzie, czy też nie będzie oparta na prawdzie genetycznej, a po drugie, zapewnienie dziecku urodzonemu w wyniku technik medycznie wspomaganej prokreacji tych samych praw w aspekcie ochrony zdrowotnego dobrostanu, które mają dzieci (osoby) urodzone w wyniku aktu płciowego swoich rodziców. O ile pierwszy z powyższych postulatów jest de lege lata możliwy do zapewnienia, o tyle drugi wiąże się z koniecznością gruntownej zmiany przepisów w zakresie wykorzystania anonimowych komórek rozrodczych.

Przeprowadzone analizy pozwalają na sformułowanie następujących nader ostrożnych wniosków końcowych. Interes zdrowotny w zakresie potencjalności osiagnięcia dobrostanu fizycznego i psychicznego człowieka przemawia za całkowitym zniesieniem dopuszczalności anonimowości dawstwa komórek

${ }_{52}$ Art. 28 comma 5: „L'adottato raggiunta l'età di venticinque anni, può accedere a informazioni che riguardano la sua origine e l'identità dei suoi genitori biologici. Può farlo anche raggiunta la maggiore età, se sussistono gravie comprovati motivi attinenti alla sua salute psico-fisica. L’istanza deve essere presentata al tribunale per i minorenni del luogo di residenza".

${ }_{53}$ Tak pkt 7.4 Rekomendacji.

${ }^{54}$ Henrion (2003); Villeneuve-Gokalp (2011). 
rozrodczych ${ }^{55}$. Nie oznacza to oczywiście pełnej jawności dawstwa i wyboru w tym zakresie. Trafne wydaje się rozwiązanie proponowane w Rekomendacji, aby tożsamość dawcy komórek nie była ujawniana na etapie zastosowania komórek w procedurze medycznie wspomaganej prokreacji, ale już ujawniana dziecku po osiagnięciu przez nie określonego wieku (np. 16 lat lub pełnoletności) ${ }^{56}$. Z nieco większą rezerwą odnieść się należy do realizacji obowiązku informacyjnego przez odpowiedni organ państwowy na temat okoliczności narodzin człowieka i wykorzystania w tym zakresie komórek pochodzących od innych niż rodzice prawni osób. Nie ulega wątpliwości, że dziecku pozostawić należy decyzję co do uzyskania dostępu do informacji o danych dawcy, niemniej jednak realizacja obowiązku o fakcie poczęcia spoczywać powinna raczej na rodzicach, a nie na państwu. Do dyskusji pozostaje także wiek, ale jak się wydaje, wyznaczenie sztywnej granicy nie jest jedynym rozwiązaniem w tym zakresie.

Zmiana powinna objąć także zakres obowiązków informacyjnych dostarczanych dawcom przed oddaniem komórek do dyspozycji służby zdrowia ${ }^{57}$. Jest oczywiste, że dawca oddając komórki rozrodcze, czyni to bez intencji nawiązania stosunku prawnego ojcostwa czy macierzyństwa. Niemniej jednak fakt niewystępowania ze stosownymi roszczeniami nie powinien przysłonić informacji o możliwości nawiązania stosunków przez dziecko po osiąnięciu przez nie określonego wieku. Oznacza to, że dawca powinien mieć świadomość faktu, że w przyszłości dziecko, pomimo braku relacji o charakterze prawnym, może zechcieć poznać dawcę komórek rozrodczych lub dawców zarodka, ewentualnie nawiązać relację o charakterze osobistym. Wiedza w tym zakresie pozwoli dawcom rozważyć, czy oddać anonimowo i altruistycznie komórki do dyspozycji służby zdrowia czy też nie. Ustawodawcy pozostawić należy natomiast decyzję o udostępnieniu informacji o rodzeństwie poczętym z tych samych komórek rozrodczych. Powyższe ma znaczenie nie tylko dla zapewnienia dobrostanu w aspekcie psychicznym (wspomniane wyżej niebezpieczeństwo kontaktów cielesnych z bratem lub siostra), lecz także dobrostanu w aspekcie fizycznym (np. w razie konieczności przeszczepu szpiku czy narządów od żywego dawcy).

$\mathrm{Z}$ aprobatą odnieść się należy do postulatu istnienia rejestru dawców anonimowych i obowiązku rejestracji osób poczętych z wykorzystaniem komórek rozrodczych pochodzacych od jednej osoby. Ma to znaczenie zarówno w aspekcie zdrowia fizycznego, jak i psychicznego. O ile pojawi się medyczna konieczność, możliwe będzie uzyskanie kontaktu z dawcą. Rejestr taki ponadto zabezpiecza górny limit ciąż uzyskanych z tych samych komórek, co - jak podniesiono wyżej - wpływa na dobrostan psychiczny. Wymóg ten musi być jednak doprecyzowany w aspekcie przepływu transgranicznego.

\section{Joanna Haberko}

Uniwersytet im. Adama Mickiewicza w Poznaniu

haber@amu.edu.pl

https://orcid.org/0000-0002-2713-3896

\footnotetext{
55 Tak pkt 7.1 Rekomendacji.

56 Tak pkt 7.2 Rekomendacji.

57 Tak pkt 7.3 Rekomendacji.
} 
Abatantuono, M. (2014/2015). Diritto dell'adottato alla ricerca delle proprie origini. (Tesi di laurea). Pisa.

Bączyk-Rozwadowska, K. (2018). Prokreacja medycznie wspomagana. Studium z dziedziny prawa. Toruń.

Ballarani, G. (2017). Modifiche all'articolo 28 della legge 4 maggio 1983, n. 184 e altre disposizioni in materia di accesso alle informazioni sulle origini del figlio non riconosciuto alla nascita (ddl n. 1978). Diritto di Famiglia e delle Persone 46(3): 963-975.

Bartels, L. (2012). Safe haven laws, baby hatches and anonymous hospital birth: examining infant abandonment, neonaticide and infanticide in Australia. Criminal Law Journal 36: 19-37.

Berti De Marinis G. (2014). Il ruolo della giurisprudenza nell'evoluzione della disciplina in tema di procreazione medicalmente assistita. Responsabilità Civile e Previdenza 79/II(4): 17161736.

Cagnazzo, A. (2017). La filiazione. Nuvi orientamenti giriusprudenziali e dottrinali. Milano.

Coutinho, J., Krell, C. (2012). Summary of the study „Anonyme Geburt und Babyklappen in Deutschland - Fallzahlen, Angebote, Kontexte Deutsches Jugendinstitut e.V., tłumaczenie na jęz. angielski z archiwum organizacji Eurochild, <https://www.dji.de/fileadmin/user_upload/Projekt_Babyklappen/Berichte/Abschlussbericht_Anonyme_Geburt_und_Babyklappen.pdf>.

Czapliński, P., Kroczek-Sawicka, Z. (2017), Prawne aspekty funkcjonowania okien życia. Białostockie Studia Prawnicze 22(2): 35-45.

Dryla, O. (2018). Dopuszczalność przeprowadzenia testów genetycznych w świetle artykułu 12 Europejskiej Konwencji Bioetycznej, [w:] A. Białek, M. Wróblewski (red.), Prawa człowieka a wyzwania bioetyczne związane z nowymi technologiami. Warszawa: 91-105.

Dyoniak, A. (1996). Wpływ woli osób bezpośrednio zainteresowanych na powstanie stosunku prawnego rodzice-dzieci w przypadku nienaturalnej prokreacji, [w:] T. Smyczyński (red.), Wspomagana prokreacja ludzka. Zagadnienia legislacyjne. Poznań: 141-160.

Gigliotti, F. (2017). Parto anonimo e accesso alle informazioni identitarie (tra soluzioni praticate e prospettive di riforma). Europa e Diritto Privato 3: 901-951.

Grosso, P.G. (2011). L'adottato alla ricerca delle proprie origini. Spunti di riflessione. Famiglia e Diritto 2: 204-212.

Grylli, Ch., Brockington, I., Fiala, Ch., Huscsava, M., Waldhoer, T., Klier, C.M. (2016). Anonymous birth law saves babies - optimization, sustainability and public awareness. Archives of Women's Mental Health 9: 291-297.

Haberko, J. (2010). Kilka uwag na temat zgody na zabieg medyczny, wyrażanej przez małżonka w trybie art. 68 Kodeksu rodzinnego i opiekuńczego. Ruch Prawniczy, Ekonomiczny i Socjologiczny 72(1): 45-57.

Haberko, J. (2011). „Szczególne względy osobiste” a przeszczep od żywego dawcy. Państwo i Prawo 66(7/8): 44-54.

Haberko, J. (2012). Stosowanie technik wspomaganej medycznie prokreacji w celach niewyłącznie rodzicielskich. Problem „dziecka-lekarstwa”. Medyczna Wokanda 4: 31-43.

Haberko, J. (2014a). „Prawo do niewiedzy” w kontekście istoty testu genetycznego jako sprawy dotyczącej całej rodziny. Zeszyty Prawnicze BAS 2(42): 5-64.

Haberko, J. (2014b). Zagrożenia dla adopcji w świetle projektu ustawy o leczeniu niepłodności. Forum Prawnicze 4: 3-15.

Haberko, J. (2015). Uznanie ojcostwa w świetle projektowanego art. $75^{1}$ k.r.o. Metryka 1: 175-194.

Haberko, J. (2016). Ustawa o leczeniu niepłodności. Komentarz. Warszawa.

Haberko, J. (2018a). Problemy filiacyjne w związku ze stosowaniem technik medycznie wspomaganej prokreacji, [w:] L. Bosek, A. Wnukiewicz-Kozłowska (red.), System prawa medycznego. Tom 2: Poszczególne przypadki świadczeń zdrowotnych. Warszawa: 169-183.

Haberko, J. (2018b). Wybrane zagadnienia macierzyństwa zastępczego, [w:] L. Bosek, A. Wnukiewicz-Kozłowska (red.), System prawa medycznego. Tom 2: Poszczególne przypadki świadczeń zdrowotnych. Warszawa: 184-195.

Haberko, J., Grabinski, A. (2011). Dobro dziecka a stosowanie procedur in vitro w prawie francuskim i prawie polskim. Studia Prawnicze 1: 33-61.

Haberko, J., Sokołowski, T. (2013). Pokrewieństwo i powinowactwo, [w:] H. Dolecki, T. Sokołowski (red.), Kodeks rodzinny i opiekuńczy. Komentarz. Warszawa: 519-619. 
Haberko, J., Sztandera F. (2017). Niebezpieczeństwo małżeństwa z bratem. Uwagi na tle ustawy o leczeniu niepłodności o prawie do poznania genetycznego pochodzenia dziecka, [w:] J. Mazurkiewicz, P. Mysiak (red.), Dobro pojemne jak krzywda. Prawna ochrona dziecka. Deklaracje a rzeczywistość. Wrocław: 98-115.

Haberko, J., Uhrynowska-Tyszkiewicz, I. (2014). Ustawa o pobieraniu, przechowywaniu i przeszczepianiu komórek, tkanek i narządów. Komentarz. Warszawa.

Hans-Bielut, P., Kroczek P. (2016). Okna życia: głos w sporze o potrzebie istnienia, [w:] L. Świtło, M. Tomkiewicz (red.), Rodzicielstwo. Wymiar społeczno-prawny. Olsztyn: 13-26.

Jarecka, A. (2019). „Poufny poród” kontra „Okno życia”. Co lepsze? <https://www.dw.com/pl/poufny-por\%C3\%B3d-kontra-okno-\%C5\%BCycia-co-lepsze-bilans/a-18421651> [dostęp: 19.11.2019].

Jolie, A. (2013). My Medical Choice. <http://www.nytimes.com/2013/05/14/opinion/my-medical-choice.html?_r=0> [dostęp: 19.11.2019].

Jóźwiak, S. (2000). Nerwiakowłókniakowatość typu I (choroba von Recklinghausena). Medycyna Praktyczna. Pediatria 3. <http://www.mp.pl/artykuly/14028> [dostęp: 19.11.2019].

Kadłubowska, L. (2018). Sytuacja prawna dzieci pozostawionych w „oknie życia”. (Praca magisterska, niepublikowana). Poznań.

Kapelańska-Pręgowska, J. (2011). Prawne i bioetyczne aspekty testów genetycznych. Warszawa.

Klier, C., Chryssa, G., Amon, S., Fiala, C., Weizmann-Henelius, G., Pruitt, S., Putkonen, H. (2012). Is the introduction of anonymous delivery associated with a reduction of high neonaticide rates in Austria? A retrospective study. BJOG: An International Journal of Obstetrics and Gynaecology 120(4): 428-434.

Krajewska, B. (2015). Okna życia w systemie opieki nad dziećmi. Warszawa.

Krekora-Zając, D. (2014). Prawo do poznania matki biologicznej według krajowego prawa rodzinnego. Studia Prawnicze 1: 131-132.

Kubicka-Kraszyńska, U. (2017). Skuteczność rozwiązań chroniących dzieci przed porzuceniem ze skutkiem śmiertelnym i dzieciobójstwem w świetle Konwencji o prawach dziecka. Dziecko Krzywdzone. Teoria, Badania, Praktyka 16(2): 65-90.

Łączkowska, M. (2008). Stosunek prawny pokrewieństwa a pochodzenie genetyczne. [w:] M. Andrzejewski, L. Kociucki, M. Łączkowska, A.N. Schulz (red.), Księga jubileuszowa Profesora Tadeusza Smyczyńskiego. Torun: 301-316.

Laing, J.A. (2006). Artificial reproduction, blood relatedness and human identity. The Monist 89(4): 548-566.

Lipski, J. (2015). Opinia prawna na temat rządowego projektu ustawy o leczeniu niepłodności. Zeszyty Prawnicze Biura Analiz Sejmowych Kancelarii Sejmu 4(48): 126-163 [dostęp: 19.11.2019].

Lo Voi, V. (2018). Mors omnia solvit? Parto anonimo e valutazione circa l'attualità del diritto all'anonimato della madre biologica nel caso di morte della stessa. Diritto di Famiglia e delle Persone 47/II(3): 1120-1142 [dostęp: 19.11.2019].

Łuczak-Wawrzyniak, J., Haberko, J. (2015). Dobrodziejstwo nowoczesnych technik wspomaganej medycznie prokreacji czy problem rodziny i dziecka? Uwagi na tle projektu ustawy o leczeniu niepłodności (druk sejmowy 3245). Diametros 44: 20-44.

Łukasiewicz, R. (2019). Dobro dziecka a interesy innych podmiotów w polskiej regulacji prawnej przysposobienia. Warszawa.

Mostowik, P. (2015). Możliwość ustalenia pochodzenia dziecka, [w:] M. Pazdan (red.), System prawa prywatnego. Tom 20C: Prawo prywatne międzynarodowe. Warszawa: 311-312.

Nesterowicz, M. (2005). Prawo pacjenta i osób bliskich do informacji i ochrona danych, [w:] W. Popiołek, L. Ogiegło, M. Szpunar (red.), Rozprawy prawnicze. Księga pamiątkowa Profesora Maksymiliana Pazdana. Kraków: 1205-1216.

Nesterowicz, M. (2010). Prawo medyczne. Torun.

Oszkinis, B. (2019). Macierzyństwo. Aspekty materialnoprawne, procesowe i kolizyjnoprawne. Warszawa.

Pietrzykowski, K. (2018). Pokrewieństwo i powinowactwo, [w:] K. Pietrzykowski (red.), Kodeks rodzinny i opiekuńczy. Komentarz. Warszawa: 556-573.

Ruszkiewicz, D. (2014). Okna życia jako instytucje wspierające dziecko i rodzinę - zalety i kontrowersje. Pedagogika Rodzinna 4: 45-58.

Safjan, M. (1990). Prawo wobec ingerencji w naturę ludzkiej prokreacji. Warszawa. 
Ministero della Salute (2019). Salute della donna. <http://www.salute.gov.it>[dostęp: 19.11.2019].

Santarsiere, V. (2009). Diritto all'anonimato della madre se al parto del figlio dichiari di non voler essere nominate. Giurisprudenza di Merito 41(6): 1529-1531.

Sants, H.J. (1964). Genealogical bewilderment in children with substitute parents. British Journal of Medical Psychology 37(2): 133-141.

Skorek, A. (2009). Testy genetyczne w interesie osób trzecich - uwagi na tle IV Protokołu dodatkowego do Europejskiej Konwencji Bioetycznej w sprawie testów genetycznych. Prawo i Medycyna 34. <https://prawoimedycyna-archiwum.com/> [dostęp: 19.11.2019].

Soniewicka, M. (2018). Selekcja genetyczna w prokreacji medycznie wspomaganej. Etyczne i prawne kryteria. Warszawa.

Szczucki, K. (2010). Prawo dziecka poczętego metodą in vitro do poznania własnej tożsamości biologicznej, [w:] L. Bosek, M. Królikowski (red.), Współczesne wyzwania bioetyczne. Warszawa: $184-198$.

Tonolo, S. (2014). I diritto alla genitorialità nella sentenza della Corte Costituzionale che cancella il divieto di fecondazione eterologa: profili irrisolti e possibili soluzioni. Rivista di Diritto Internazionale 97(4): 1123-1147.

Velletti, M. (2017). Diritto alla conoscenza delle origini, [w:] Trattato di diritto e bioetica. Napoli: 409-416.

Villeneuve-Gokalp, C. (2011). Women who give birth „secretly” in France, 2007-2009. Population-E 66(1): 131-168.

Vitale, F. (2019). Il parto in anonimato: analisi della normative. <https://www.senato.it/japp/bgt/ showdoc/17/DOSSIER/0/929566/index.html?part=dossier_dossier1> [dostęp: 19.11.2019].

Żok A., Rzymska, I. (2015). Problem okien życia - analiza etyczno-prawna. Poznańskie Zeszyty Humanistyczne 25: 2-19.

\author{
THE ANONYMITY OF GENETIC PARENTS \\ AND THE HEALTH-RELATED WELL-BEING OF THE CHILD: \\ REMARKS IN THE LIGHT OF RECOMMENDATION 2156(2019) OF \\ THE PARLIAMENTARY ASSEMBLY OF THE COUNCIL OF EUROPE
}

Sum mary

The text presents the problem of the health interest of a child conceived as a result of the use of medically assisted procreation techniques using donor genetic material. The use of modern medical technology is becoming increasingly common nowadays and the procedures which a few years ago were seen as experimental are now becoming standard. The present text covers the issues of risks and conflicts for family members related to the use of technology for the conception and birth of a child. The issue is the physical and mental well-being that can be derived from knowing one's origin from specific persons. Polish law does not provide access to information enabling the identification of a donor of reproductive cells, and the restrictions on the information that can be provided to an authorized person have been narrowly defined. This allows the formulation of the thesis, which is verified in the text, that the Polish legislator does not ensure the implementation of the right to know one's own genetic identity as the right to information in the field of donor genome, and even more so the right to know the identity of gamete donors as the right to information in terms of donor identification data. The text presents postulates based on Italian solutions and Recommendation 2156(2019) of the Parliamentary Assembly of the Council of Europe.

Keywords: well-being; relative; the right to know one's origin; identity 